\title{
Effects of Soil Type on Floristics and Stand Structure in Amazon Unflooded Forests
}

\author{
Randall W. Myster ${ }^{1}$ \\ ${ }^{1}$ Biology Department, Oklahoma State University, Oklahoma City, OK. 73107, USA \\ Correspondence: Randall W. Myster, Biology Department, Oklahoma State University, Oklahoma City, OK. \\ 73107, USA. E-mail: myster@okstate.edu
}

Received: April 18, 2018

Accepted: May 18, 2018 Online Published: June 18, 2018

doi:10.5539/jps.v7n2p20

URL: https://doi.org/10.5539/jps.v7n2p20

\begin{abstract}
The importance of unflooded forests in the Amazon and the need to investigate how their soils affect their floristics and stand structure, lead me to set up and sampled trees in four plots in terra firme forest, in white sand forest and in palm forest at the same site in the Peruvian Amazon. I found (1) the white sand forest plot had 15 families with Clusiaceae, Malvaceae and Myrtaceae the most common and Pachira brevipes the most common species, (2) the palm forest plot had 6 families with Arecaceae, Clusiaceae and Fabaceae the most common and Socratea exorrhiza the most common species, and (3) the terra firme forest plot had 47 families with Myristicacea, Fabaceae and Bombacace the most common and Otoba parvifolia and Astrocaryum murumura the most common species. For the stand structure of these forests, (1) terra firme had more stems and larger stems than white sand and palm, and while palm had more stems than white sand, white sand had larger stems than palm, (2) species richness was greatest in terra firme and decreased by a factor of three in white sand, and by a factor of five in palm, (3) basal area decreased from terra firme to white sand, but white sand and palm were comparable, (4) white sand had the greatest above-ground biomass, followed by terra firme and palm, and (5) white sand and palm were much more open forests than terra firme. Results strongly suggest that soils are a significant causal factor in determining floristic and structural differences among these Amazon forests, where the richer soil of terra firme forest helps produce both more structure and a richer floristics compared to the poor soil of palm forests and the even poorer soil of white sand forests.
\end{abstract}

Keywords: palm forest, Peru, Sabalillo Forest Reserve, terra firme forest, white sand forest

\section{Introduction}

Plant communities in the Amazon are among the most critical ecosystems to life on earth (Walter, 1973). They are the most productive (Daly and Prance, 1989) and diverse forests (Pires and Prance, 1985), and influence worldwide weather patterns and climate (Keller et al., 2004). They are also key to the functioning of the earth's biogeochemical cycles. For example, in the Carbon cycle these rainforests act as a large carbon "sink" when they take in large amounts of $\mathrm{CO}_{2}$ through photosynthesis, and a large carbon "source" when their trees decay or burn. The majority of Amazonian rainforests are unflooded, even though they are located in areas lower than $100 \mathrm{~m}$ elevation above sea level. The three most common of these unflooded forests differ fundamentally in their soils (1) terra firme forests found on clay or loam soils, (2) white sand forests on soils with a large amount of quartz (leading extremely infertile soils with low pH and low water retention capacity: Ruokolainen et al., 1997), and (3) palm forests on standing water or water-logged clay (Terborgh and Andresen, 1998; Tuomisto et al., 2003).

Terra firme forests share much of their stand structure with unflooded rainforests throughout the rest of the Neotropics (Kalliola et al., 1991; Everham et al., 1996; Pitman et al., 2001; Tuomisto et al., 2003). Palm forests occur in depressions and low-lying areas of poor drainage (Svenning, 1999a; Pitman et al., 2014), and have a canopy of 12-30 m with arborescent palms and other trees (Myster, 2009). White sand forests have a shorter canopy with a lighter understory than terra firme forests (Medina and Cuevas, 1989) and a flora rich in endemics (Frasier et al., 2008) where herbivory defense is a major factor in defining and differentiating among their tree species (Fine et al., 2004; Fine et al., 2006). Compared to terra firme forests, both white sand forests and palm forests are under significant stress (Fine et al., 2010; Pitman et al., 2014; Myster, 2016b) due to soil nutrient deficiency (in the case of white sand forest) or being water-logged and having $\mathrm{O}_{2}$ deficiency (in the case of palm forest: Myster, 2017c). 
Whereas Amazon soils can affect species distributions, and community floristics and stand structure (Ruokolaimen et al., 2007), soil differences among unflooded Amazon forests in particularly allow an investigation into how Amazon soils affect forest floristics and stand structure. Consequently I expand on past sampling of these types of unflooded Amazon forests (Svenning, 1999a; Vormisto et al., 2000; Honorio, 2006; Montafar and Pintaud, 2006; Normand et al., 2006; Pitman et al., 2008; Fine et al., 2010) by setting up and sampling four plots in a terra firme forest, four plots in a white sand forest, and four plots in a palm forest. Unique to this study, however, all plots are at the same study site and within $100 \mathrm{~m}$ of each other, which increases the probability that any differences in floristics and stand structure are due to edaphic variation. I then use the plot data to address these three questions (1) What species, genera, and families are found in terra firme forest, in white sand forest, and in palm forest, all common unflooded forests in the Amazon?, (2) What is the stand structure of those forests? and (3) What do the results suggest about how the edaphic conditions of these forests may affect their floristics and stand structure?

\section{Methods}

\subsection{Study Area}

The study was conducted at Sabalillo Forest Reserve (SFR: $3^{\circ} 20^{\prime} 3^{\prime \prime} \mathrm{S}, 72^{\circ} 18^{\prime}$ 6" W: Frederickson et al., 2005; Moreau, 2008), was established in 2000 and is operated by Project Amazonas (www.projectamazonas.org). SFR is located on both sides of the upper Rio Apayacu, $172 \mathrm{~km}$ east of Iquitos, Peru. The reserve is part of 10,117 ha set aside over the last decade. Annual precipitation is $3.297 \mathrm{~m}$ per year (Choo et al., 2007) and the rainy season is between November and April. All three study forests are common at SFR: white sand forest on soils of extreme infertility made up mainly of quartz podzols, palm forest on standing water with clay soils, and terra firme forest on loam soils.

\subsection{Plot Set-up and Sampling}

In June 2013, two local student field assistants and I set up four $(50 \mathrm{~m}$ x $50 \mathrm{~m})$ plots in terra firme forest, four $(50 \mathrm{~m} \times 50 \mathrm{~m})$ plots in white sand forest, and four $(50 \mathrm{~m} \times 50 \mathrm{~m})$ plots in palm forest, in 12 separate stands at SFR at typical locations suggested by the field assistants. All plots are located in the same study area and were at least $50 \mathrm{~m}$ apart. Consequently, while other studies could only suggest that these soils are influencing floristics and stand structure in these forests, I can make a stronger argument because effects of other potential causal factors (e.g., climate, rainfall, temperature) are in common among all the plots. We measured the diameter at breast height (dbh) of all trees at least $10 \mathrm{~cm}$ dbh in each of the 12 plots. The dbh measurement was taken at the nearest lower point where the stem was cylindrical and for buttressed trees, it was taken above the buttresses. Plots of this size have been used to study forest floristics and structure in the Amazon for decades (see Myster, 2009 and chapters in Myster, 2017a; Myster, in press) and past publications using data from the terra firme plots (Myster, 2016b) have shown them to be typical of terra firme forests sampled by others in Western Amazonia. Trees were also identified to species, or to genus in a few cases, using Romoleroux et al., (1997) and Gentry (1993) as taxonomic sources. We also consulted the Universidad Nacional de la Amazonia Peruana herbarium in Iquitos and the web site of the Missouri Botanical Garden 〈www.mobot.org〉.

\subsection{Data Analysis}

Using the collected data, I first compiled floristic tables of family, genus and species for each forest after combining their four plots into a single 1 ha plot. I then generated, for each forest (1) the total number of stems, the mean dbh among those stems, and the total number of stems divided into four size classes: $10<20 \mathrm{~cm} \mathrm{dbh}$, $20<30 \mathrm{~cm} \mathrm{dbh}, 30<40 \mathrm{~cm} \mathrm{dbh}$ and $\geq 40 \mathrm{~cm} \mathrm{dbh}$, (2) species richness, (3) total basal area (the sum of the basal areas of all individual stems which is $\pi^{*} \mathrm{r}^{2}$ where $\mathrm{r}=$ the dbh of the individual stem / 2), (4) above-ground biomass (AGB) using the formula in Nascimento and Laurance (2001) suggested for Amazonian trees of these stem sizes and (5) canopy closure using the formula in Buchholz et al., (2004) for tropical trees with the resulting percentage of the combined 1 ha plot area closed.

\section{Results and Discussion}

\subsection{Floristics}

There were 47 families found in the terra firme plot (Table 1) and Myristicacea was the most common family with Fabaceae and Bombacace common as well. There were 17 families with only one stem. There were 15 families found in the white sand plot (Table 1). Clusiaceae was by far the most common family, which also had the most genera and the most species. Malvaceae, Myrtaceae and Rubiaceae were also common, and there were two families (Arecaceae, Moraceae) with only one stem. There were six families found in the palm plot (Table 1). Arecaceae was by far the most common family, which also had the most genera and the most species. Clusiaceae, 
Fabaceae and Lecythidaceae were also common, and there was only one family (Opiliaceae) with only one stem. White sand forest had only four families with stems in palm forest but 15 families with stems in terra firme forest. Palm forest had only five families with stems in terra firme forest (Table 1).

Table 1. All families found in the white sand, palm and terra firme combined 1 ha plots sorted alphabetically with the number of tree stems sampled given under each forest-type

\begin{tabular}{|c|c|c|c|}
\hline Family & white sand & palm & terra firme \\
\hline Anacardiaceae & 0 & 0 & 4 \\
\hline Annonaceae & 11 & 0 & 36 \\
\hline Apocynaceae & 0 & 0 & 1 \\
\hline Araliaceae & 0 & 0 & 2 \\
\hline Arecaceae & 1 & 235 & 30 \\
\hline Bignoniaceae & 0 & 0 & 1 \\
\hline Bombacace & 0 & 0 & 50 \\
\hline Boraginaceae & 0 & 0 & 4 \\
\hline Burseraceae & 23 & 0 & 18 \\
\hline Capparidacea & 0 & 0 & 1 \\
\hline Caricaceae & 0 & 0 & 3 \\
\hline Cecropiacea & 0 & 0 & 5 \\
\hline Chrysobalanaceae & 0 & 0 & 9 \\
\hline Clusiaceae & 127 & 98 & 1 \\
\hline Dichapetalaceae & 0 & 0 & 1 \\
\hline Elaeocarpaceae & 3 & 0 & 1 \\
\hline Euphorbiaceae & 3 & 8 & 18 \\
\hline Fabaceae & 7 & 57 & 55 \\
\hline Flacourtacea & 0 & 0 & 7 \\
\hline Humiviaceae & 0 & 15 & 0 \\
\hline Icacinaceae & 5 & 0 & 1 \\
\hline Lauraceae & 0 & 0 & 19 \\
\hline Lecythidacea & 0 & 36 & 18 \\
\hline Malpighiacea & 0 & 0 & 1 \\
\hline Malvaceae & 86 & 0 & 0 \\
\hline Melastomataceae & 0 & 0 & 1 \\
\hline Meliaceae & 0 & 0 & 22 \\
\hline Memecyle & 0 & 0 & 1 \\
\hline Moraceae & 1 & 0 & 22 \\
\hline Myristicacea & 0 & 0 & 56 \\
\hline Myrtaceae & 64 & 0 & 6 \\
\hline Nyctaginaceae & 0 & 0 & 9 \\
\hline Olacaceae & 0 & 0 & 1 \\
\hline Opiliaceae & 0 & 1 & 0 \\
\hline Polygonaceae & 0 & 0 & 4 \\
\hline Quiinaceae & 0 & 0 & 1 \\
\hline Rhizoporaceae & 0 & 0 & 1 \\
\hline Rubiaceae & 48 & 0 & 4 \\
\hline Sabiaceae & 0 & 0 & 1 \\
\hline Sapindaceae & 10 & 0 & 2 \\
\hline Sapotaceae & 3 & 0 & 42 \\
\hline Simaroubaceae & 0 & 0 & 1 \\
\hline Siparunaceae & 9 & 0 & 4 \\
\hline Staphyleaceae & 0 & 0 & 1 \\
\hline Sterculiaceae & 0 & 0 & 17 \\
\hline Tiliaceae & 0 & 0 & 8 \\
\hline Ulmaceae & 0 & 0 & 6 \\
\hline Urticaceae & 0 & 0 & 3 \\
\hline Verbenace & 0 & 0 & 1 \\
\hline Violaceae & 2 & 0 & 4 \\
\hline Vochysiaceae & 16 & 0 & 0 \\
\hline
\end{tabular}

The most common species in terra firme forest were Otoba parvifolia and Astrocaryum murumura, in white sand forest Pachira brevipes and Caraipa tereticaulis, and in palm forest Socratea exorrhiza and Lepidocaryum tenue (Table 2). Among those most common species only one genera (Caraipa) and one species (Oenocarpus bataua) were found both in white sand forest and in palm forest. There were two genera in common between palm forest and terra firme forest (Astrocaryum, Eschweilera) but no species in common between terra firme forest and either white sand forest or palm forest (Table 2). 
Table 2. All species in the combined 1 ha white sand plot, in the combined 1 ha palm plot and in the combined 1 ha terra firme plot, with at least 4 stems and sorted by family first, then genus and finally species

\begin{tabular}{|c|c|c|c|}
\hline \multicolumn{4}{|l|}{ white sand forest plot } \\
\hline Family & Genus & Species & number of stems \\
\hline Arecaceae & Oenocarpus & bataua & 4 \\
\hline Clusiaceae & Calophyllum & brasiliense & 5 \\
\hline Clusiaceae & Caraipa & tereticaulis & 15 \\
\hline Clusiaceae & Haploclathra & cordata & 7 \\
\hline Clusiaceae & Tovomita & calophyllophylla & 9 \\
\hline Fabaceae & Dicymbe & puncticulosa & 8 \\
\hline Fabaceae & Macrolobium & microcalyx & 5 \\
\hline Fabaceae & Tachigali & paniculata & 9 \\
\hline Malvaceae & Pachira & brevipes & 19 \\
\hline $\begin{array}{l}\text { Sapindaceae } \\
\text { palm forest plot }\end{array}$ & Cupania & diphylla & 4 \\
\hline Family & Genus & Species & number of stems \\
\hline Arecaceae & Astrocaryum & javarense & 8 \\
\hline Arecaceae & Euterpe & precatoria Mart. & 8 \\
\hline Arecaceae & Geonoma & macrostachys Mart. var. acaulis & 14 \\
\hline Arecaceae & Lepidocaryum & tenue Mart. var. tenue & 31 \\
\hline Arecaceae & Mauritia & flexuosa & 9 \\
\hline Arecaceae & Oenocarpus & bataua & 25 \\
\hline Arecaceae & Socratea & exorrhiza & 44 \\
\hline Clusiaceae & Caraipa & valioi & 5 \\
\hline Euphorbiaceae & Hura & crepitans & 4 \\
\hline Fabaceae & Crudia & glaberrima & 4 \\
\hline $\begin{array}{l}\text { Lecythidaceae } \\
\text { terra firme forest pl }\end{array}$ & Eschweilera & bracteosa & 7 \\
\hline Family & Genus & Species & number of stems \\
\hline Annonaceae & Unonopsis & floribunda & 4 \\
\hline Arecaceae & Astrocaryum & murumura & 20 \\
\hline Arecaceae & Iriartea & deltoidea & 15 \\
\hline Bombacacea & Eriotheca & macrophylla & 4 \\
\hline Bombacacea & Matisia & bracteolosa & 6 \\
\hline Bombacacea & Matisia & malacocalyx & 8 \\
\hline Bombacacea & Matisia & ochrocalyx & 6 \\
\hline Bombacacea & Pachira & insignis & 4 \\
\hline Bombacacea & Quararibea & loretoyacuensis & 6 \\
\hline Burseracea & Protium & amazonicum & 4 \\
\hline Burseracea & Tetragastris & panamensis & 5 \\
\hline Cecropiacea & Cecropia & sciadophylla & 4 \\
\hline Chrysobalanaceae & Licania & macrocarpa & 5 \\
\hline Euphorbiacea & Nealchornea & yapurensis & 6 \\
\hline Fabaceae & Bauhinia & brachycalyx & 5 \\
\hline Fabaceae & Erythrina & poeppigiana & 4 \\
\hline Fabaceae & Inga & oerstediana & 9 \\
\hline Fabaceae & Platymiscium & stipulare & 5 \\
\hline Fabaceae & Pseudopiptadenia & suaveolens & 6 \\
\hline Lecythideacea & Eschweilera & gigantean & 5 \\
\hline Meliaceae & Carapa & guianensis & 4 \\
\hline Meliaceae & Guarea & kunthiana & 4 \\
\hline Moraceae & Perebea & xanthochyma & 7 \\
\hline Moraceae & Pseudolmedia & laevis & 7 \\
\hline Myristicacea & Iryanthera & paraensis & 8 \\
\hline Myristicacea & Otoba & glycicarpa & 11 \\
\hline Myristicacea & Otoba & parvifolia & 23 \\
\hline Nyctaginacea & Neea & spruceana & 5 \\
\hline Sapotaceae & Pouteria & krukovii & 5 \\
\hline Siparunacea & Siparuna & cristata & 4 \\
\hline Tiliaceae & Apeiba & aspera & 4 \\
\hline Urticaceae & Urera & caracasana & 6 \\
\hline Violaceae & Leonia & glycycarpa & 4 \\
\hline
\end{tabular}

\subsection{Stand Structure}

Terra firme had more stems and larger stems than white sand and palm, and while palm had more stems than 
white sand, white sand had larger stems than palm (Table 3). For all three forests, stems conformed to a "reverse J" size distribution pattern. Species richness was greatest in terra firme and decreased by a factor of three in white sand, and by a factor of five in palm. Basal area decreased from terra firme to white sand, but white sand and palm were comparable. White sand had the greatest above-ground biomass, followed by terra firme and palm. White sand and palm were much more open forests than terra firme (Table 3).

Table 3. Stand structure parameters for all trees at least $10 \mathrm{~cm}$ dbh sampled in the combined 1 ha plots

\begin{tabular}{llll}
\hline parameter & white sand & palm & terra firme \\
\hline Stem density: & & & \\
\hline Total & 403 & 449 & 519 \\
$10<20 \mathrm{dbh}$ & 241 & 253 & 288 \\
$20<30 \mathrm{dbh}$ & 95 & 176 & 121 \\
$30<40 \mathrm{dbh}$ & 63 & 20 & 50 \\
40 or greater & 3 & 0 & 60 \\
mean dbh & 19.8 & 14.1 & 20.8 \\
$\begin{array}{l}\text { Species richness } \\
\left.\text { Basal area (m }{ }^{2}\right)\end{array}$ & 103 & 57 & 302 \\
$\begin{array}{l}\text { Above-ground } \\
\text { biomass }(\mathrm{Mg})\end{array}$ & 387.7 & 11.15 & 17.6 \\
$\begin{array}{l}\text { Canopy: } \\
\text { Closure (m2) }\end{array}$ & 1441.2 & 267.1 & 334.2 \\
per ha (\%) & 14.412 & 2356.7 & 6921.4 \\
\hline
\end{tabular}

While edaphic conditions have been suggested as causal factors in determining floristic and structural differences among these three Amazon forest-types before (Svenning, 1999a; Vormisto et al., 2004; Honorio, 2006; Montafar and Pintaud, 2006; Normand et al., 2006; Pitman et al., 2008; Fine et al., 2010), here that suggestion is much stronger because other possible factors (e.g., rainfall, climate, temperature) are very similar among the plots. There were very few species and genera in common among the three forests and so soils seem to associate with, and perhaps help to cause, their own unique flora. Among the taxa, there was more similarity on the familial taxonomic level consistent with the hypothesis that a small number of plant families dominate in the Neotropic (Oligarchies: Honorio-Corondo, 2009). The edaphic conditions found in white sand forest and palm forest reduced tree stem density to a degree, and palm forest had smaller stems than the other two forest-types. White sand forest had a reduction to $1 / 3$ of the species richness of terra firme and palm forest was half that of white sand forest. Basal areas were similar in white sand forest and palm forest, but both were less than terra firme. White sand forest had more above-ground biomass than terra firme forest. Soils with reduced nutrients (white sand forest) and those that were waterlogged (palm forest) were found with more open canopies compared to terra firme forest.

Pittman et al. (2008) sampled plots the same size, shape, and lower stem size limit as this study, and found a major floristic discontinuity between terra firme and white sand forest in the western Amazon, thought to depend on soil characteristics (Fine et al., 2007; Vormisto et al., 2000). Fine et al. (2010) sampled mainly 0.1 ha white sand plots at a minimum stem size of $5 \mathrm{~cm}$ dbh and found a species richness of 41.5 on average which was smaller than terra firme forests, and a different species composition than terra firme forest (as seen here) with 83\% endemics found only in white sand forest and dominance by a relatively few species. The species found in those plots, were very similar to mine, but in smaller white sand plots (Fine et al., 2010). The low soil nutrients in white sand forest may have been the cause of the reduction in stem density and species richness, compared to terra firme forests, but did not affect the size structure of those stems.

In addition to the comparisons of white sand forest, palm forest and terra firme forest made here, it is useful to also compare the results to one ha plots (again all trees with a dbh at least $10 \mathrm{~cm}$ ) sampled in white-water flooded forest in Ecuador (várzea: flooded 1 month per year) and sampled in black-water flooded forest in Peru (igapó: flooded 3-4 months per year) where I computed the same structural parameters (Myster, 2015; Myster, 2016a; Myster, 2016b). Floristic similarity is still low between white sand and these two flooded forests at genus and species levels. The number of families in white sand (15) different from várzea (at 41) but similar to igapó (at 16). But there are few families they have in common (4 white sand families out of 16 in igapó, 12 white sand families out of 41 in várzea). Rankings of the common families are also different. For example, whereas Fabaceae is easily the most common family in both flooded forests, it ranks only ninth in the white sand forest, and where Cluciaceae is the most common in the white sand forest, it ranks $21^{\text {st }}$ in the várzea forest and is not found in igapó. This floristic comparison suggests that white sand may become similar to igapó forest in number of families when flooded is at least 4 months per year. Terra firme and várzea were similar in families while 
palm remained largely unique.

In terms of stand structure, the white sand forest ( $403 \mathrm{stems} / \mathrm{ha})$ is closer to várzea ( $573 \mathrm{stems} / \mathrm{ha})$ than to igapó (167 stems/ha). There were more, large trees in both flooded forests, however, and more species in both várzea (185 species/ha) and igapó (120 species/ha) compared to 103 species in the one ha white sand plot. White sand basal area and aboveground biomass was between the two flooded forests due to the increased number of stems, but várzea was more closed $(44.7 \%)$ than either white sand $(14.4 \%)$ or igapó $(12.3 \%)$. Several structural parameters continue to suggest that white sand may be similar in structure (and some families) to igapó forests that are flooded more than 4 months per year (Myster, 2007; Myster, 2010; Myster, 2015; Myster, 2016a; Myster, 2016b). Compared to terra firme forests both white sand forest and flooded forests lose stems, but flooded forests maintain a greater number of larger trees than both unflooded forests - white sand, terra firme - and so their stem distribution is more of a "saddle" than a monotonic decline in numbers with increasing size (Myster, 2016b). As flooding increased, there was increased basal area and fewer trees, genera, and species (Myster, 2010). Both reduced soil nutrients and flooding tend to eliminate both vertical and horizontal heterogeneity affecting, for example, the availability of commonly logged tree species and animal populations. The white sand plot suggests that loss of soil fertility may have similar effects on certain forest structural parameters as flooding, for some black-water forests at least.

Species identity in the palm study plot compared well with other palm forest samplings in the western Amazon (Svenning, 1999a; Vormisto et al., 2000, Montufar and Pintaud, 2006; Normand et al., 2006) but structural analysis in palm forests has not been done before and so data was not available for comparison. The reduction in species richness for palm forests, compared to other terra firme forests, has also been predicted (Normand et al., 2006). Sitting water in palm forest leads to less stems and smaller stems compared to terra firme forest as does flooding, but flooded forests maintain a greater number of larger trees and so their stem distribution is more of a "saddle" than a monotonic decline in numbers with increasing size (Myster, 2016b). This is seen in the increased basal area and leading to fewer trees, genera, and species as flooding increased (Myster, 2007; Myster, 2010). Both standing water and flooding tend to eliminate both vertical and horizontal heterogeneity affecting, for example, the availability of commonly logged tree species and animal populations. Results suggest that loss of soil fertility and standing water in unflooded forests may have similar effects on certain forest structural parameters as flooding of both white-water and black-water.

Finally, tree seed studies have shown that in terra firme forest seed predators took most seeds regardless of species, in palm forest species were different regardless of seed mechanism and tolerance, and in white sand forest seed predators took most seeds regardless of species. That is while seed predation losses strength as forests become more stressed by loss of soil fertility, seed pathogens become more important with water-logged soils (Myster, 2017b). These permanent plot studies, and others like them in the Amazon, provide baseline data on forest dynamics and fluctuations of forest structure which are due to plant-plant replacement (Myster, 2012; Myster, 2017a). This knowledge will enable conservationists to develop sound management techniques for these forests in order to better utilize them as societal and human needs arise in the future. Sustainability of these flooded systems in the Amazon is critical for the lives of the local peoples that live there but also for the rest of us.

\section{Acknowledgements}

I thank Dr. Juan Celedonio Ruiz Macedo of the Universidad Nacional de la Amazonia Peruana (UNAP) herbarium, and UNAP students Christian Renan Silva Arirama and Josias Tello Huanaquiri, for taxonomic assistance.

\section{References}

Buchholz T., Tennigkeit, T., \& Weinreich A. (2004). Maesopsis eminii - a challenging timber tree species in Uganda - a production model for commercial forestry and smallholders. Proceedings of the international union of forestry research organizations (IUFRO) conference on the economics and management of high productivity plantations, Lugo, Spain, 15p.

Choo, J. P. S., Martinez R. V., \& Stiles E. W. (2007). Diversity and abundance of plants with flowers and fruits from October 2001 to September 2002 in Paucarillo Reserve, Northeastern Amazon. Peru Revisita Peru Biology, 14, 25-31.

Daly, D. G., \& Prance, G. T. (1989). Brazillian Amazon. Pp 401-426 in Campbell D. G. \& Hammond H. D. (eds) Floristic inventory of tropical countries. New York Botanical Garden, Bronx, NY.

Everham, E. M. III, Myster, R. W., \& Vandergenachte, E. (1996). Effects of light, moisture, temperature and 
litter on the regeneration of five tree species in the tropical montane wet forest of Puerto Rico. America Journal of Botany, 83, 1063-1068. https://doi.org/10.1002/j.1537-2197.1996.tb12804.x

Fine, P. V., Mesones, A. I., \& Coley, P. D. (2004). Herbivores promote habitat specialization by trees in Amazonian forests. Science, 305, 663-665. https://doi.org/10.1126/science.1098982

Fine, P. V. A., Miller, Z. J., Mesones, I., Irazuzta, S., Appel, H. M., Stevens, H. H., Saaksjarvi, I., Schultz, J. C., \& Coley, P. D. (2006). The growth-defense tradeoff and habitat specialization by plants in Amazonian forests. Ecology, 87, 150-162. https://doi.org/10.1890/0012-9658(2006)87[150:TGTAHS]2.0.CO;2

Fine, P. V. A., Daly, D. C., \& Cameron, K. M. (2007). The contribution of edaphic heterogeneity to the evolution and diversity of Burseraceae trees in the Western Amazon. Evolution, 59, 1464-1478.

Fine, P. V. A., Garcia-Villacorta, R., Pitman, N. C. A., Mesones, I., \& Kembel, S. W. (2010). A floristic study of the white-sand forests of Peru. Annuals of the Missouri Botanical Gardens, 97, 283-305. https://doi.org/10.3417/2008068

Frasier, C. L., Albert, V. A., \& Struwe, L. (2008). Amazonian lowland, white sand areas as ancestral regions for South American biodiversity: Biogeographic and phylogenetic patterns in Potalia (Angiosperme: Gentianaceae). Organismal Division of Evolution, 8, 44-57. https://doi.org/10.1016/j.ode.2006.11.003

Frederickson, M. E., Greene, M. J., \& Gordon, D. M. (2005). 'Devil's garden' bedeviled by ants. Nature, 437, 495-496. https://doi.org/10.1038/437495a

Gentry, A. (1993). A field guide to woody plants of northwest South America (Colombia, Ecuador, Peru). Conservation International, Washington, DC

Honorio, E. N. (2006). Floristic relationships of the tree flora of Jenaro Herrera, an unusual area of the Peruvian Amazon. M. S. thesis, University of Edinburgh, Edinburgh, UK. Pp 104.

Honorio Coronado E. N., Baker, T. R., Phillips, O. L., Pitman, N. C. A., Pennington, R. T., ... Freitas-Alvarado P. (2009). Multi-scale comparisons of tree composition in Amazonian terra firme forests. Biogeosciences, 6 , 2719-2731. https://doi.org/10.5194/bg-6-2719-2009

Kalliola, R., Jukka, S., Puhakka, M., \& Rajasilta, M. (1991). New site formation and colonizing vegetation in primary succession on the western Amazon floodplains. Journal of Ecology, 79, 877-901. https://doi.org/10.2307/2261087

Keller, M., Alencar, A., Asner, G. P., Braswell, B., Bustamante, M., Davidson, E., ... Vourlitis, G. L. (2004). Ecological research in the large-scale biosphere atmosphere experiment in Amazonia: early results. Ecological Applications, 14, S3-S16. https://doi.org/10.1890/03-6003

Medina, E., \& Cuevas, E. (1989). Patterns of nutrient accumulation and release in Amazonian forests of the upper Rio Negro basin. Pp.217-240 in Protor, J (editor) Mineral nutrients in tropical forest and savanna ecosystems. Blackwell Scientific, Oxford.

Montufar, R., \& Pintaud, J. C. (2006). Variation in species composition, abundance and microhabitat preferences among western Amazonian terra firme palm communities. Botanical Journal of the Linninus Society, 151, 127-140. https://doi.org/10.1111/j.1095-8339.2006.00528.x

Moreau, C.S. (2008). Unraveling the evolutionary history of the hyperdiverse ant genus Pheidole (Hymenoptera: Formicidae). Molecular Stand Evolution, 48, 224-239. https://doi.org/10.1016/j.ympev.2008.02.020

Myster, R. W. (2007). Interactive effects of flooding and forest gap formation on tree composition and abundance in the Peruvian Amazon. Folia Geobotanical, 42, 1-9. https://doi.org/10.1007/BF02835099

Myster, R. W. (2009). Plant communities of Western Amazonia. The Botanical Review, 75, 271-291. https://doi.org/10.1007/s12229-009-9032-1

Myster, R. W. (2010). Flooding duration and treefall gap interactive effects on plant community structure, richness and alpha diversity in the Peruvian Amazon. Ecotropica, 16, 43-49.

Myster, R. W. (2012). Plants replacing plants: the future of community modeling and research. The Botanical Review, 78, 2-9. https://doi.org/10.1007/s12229-011-9091-y

Myster, R. W. (2015). Várzea forest vs. terra firme forest floristics and stand structure in the Ecuadorean Amazon. Ecotropica, 20, 35-44.

Myster, R. W. (2016a). Black-water forests (igapo) vs. white-water forests (varzea) in the Amazon: Floristics and stand structure. Biologist (Lima), 13, 391-406. 
Myster, R. W. (2016b). The stand structure of Amazon forests: a review. The Botanical Review, 82, 407-427. https://doi.org/10.1007/s12229-016-9174-x

Myster, R. W. (2017a). Conclusions, synthesis and future directions. Pp 197-204 in Forest structure, function and dynamics in Western Amazonia. Myster, R. W. (ed). Wiley and sons, Oxford, UK.

https://doi.org/10.1002/9781119090670

Myster, R. W. (2017b). Comparing and contrasting flooded and unflooded forests in Western Amazonia: seed predation, seed pathogens, germination. Community Ecology, 18, 169-174.

https://doi.org/10.1556/168.2017.18.2.6

Myster, R. W. (2017c). A comparison of the forest soils in the Peruvian Amazon: Terra firme, palm, white sand and igapó. Journal of Soil Science and Environmental Management, 8, 130-134. https://doi.org/10.5897/JSSEM2017.0644

Myster, R. W. in press. Igapó (black-water flooded forests) of the Amazon basin. Springer-Verlag, Berlin.

Nascimento, H. E. M., \& Laurance, W. F. (2001) Total aboveground biomass in central Amazonian rainforests: a landscape-scale study. Forest Ecology and Management, 157, 1-11.

Normand, S., Vormisto, J., Svenning, J. C., Grandez, C., \& Balslev, H. (2006). Geographical and environmental controls of palm beta diversity in paleo-riverine terrace forests in Amazonian Peru. Plant Ecology, 186, 161-176. https://doi.org/10.1007/s11258-006-9120-9

Pires, J. M., \& Prance, G. T. (1985). The vegetation types of the Brazilian Amazon. Pp 109-145 in: Prance G.T. \& Lovejoy T. E. (eds) Amazonia. Pergamon press, Oxford.

Pitman, N. C., Terborgh, J. W., Silman, M. R., Nunez, P. V., Neill, D. A., Ceron, C. E., Palacios, W., \& Aulestia, M. (2001). Dominance and distribution of tree species in upper Amazonian terra firme forests. Ecology, 82, 2101-2117. https://doi.org/10.1890/0012-9658(2001)082[2101:DADOTS]2.0.CO;2

Pitman, N. C. A., Mogollon, H., Davila, N., Rios, M., Garcia-Villacorta, R., Guevara, J., ... Valderrama, E. (2008). Tree community change across $700 \mathrm{~km}$ of lowland Amazonian forest from the Andean foothills to Brazil. Biotropica, 40, 525-535. https://doi.org/10.1111/j.1744-7429.2008.00424.x

Pitman, N. C. A., Andino, J. E. G., Aulestia, M., Ceron, C. E., Neill, D. A., Palacios, W., \& Terborgh, J. W. (2014). Distribution and abundance of tree species in swamp forests of Amazonian Ecuador. Ecography, 37, 902-915. https://doi.org/10.1111/ecog.00774

Romoleroux, K., Foster, R., Valencia, R., Condit, R., Balslev, H., \& Losos, E. (1997). Especies Lenosas (dap => $1 \mathrm{~cm}$ ) encontradas en dos hectareas de un bosque de la Amazonia ecuatoriana. Pp 189-215 in Valencia R., \& Balslev H. (eds) Estudios Sobre Diversidad y Ecologia de Plantas. Pontificia Universidad Catolica del Ecuador, Quito, Ecuador.

Ruokolainen, K., Tuomisto, H., Macia, M. J., Higgins, M. A., \& Yli-Halla, M. (2007). Are floristic and edaphic patterns in Amazonian rain forests congruent for trees, Pteridophytes and Melastomataceae?. Journal of Tropical Ecology, 23, 13-25. https://doi.org/10.1017/S0266467406003889

Ruokolainen, K., Linna, A., \& Tuomisto, H. (1997). Use of Melastomataceae and pteridophytes for revealing phytogeographical patterns in Amazonian rain forests. Journal of Tropical Ecology, 13, 243-256. https://doi.org/10.1017/S0266467400010439

Svenning, J. C. (1999). Microhabitat specialization in a species-rich palm community in Amazonian Ecuador. Journal of Ecology, 87, 55-65. https://doi.org/10.1046/j.1365-2745.1999.00329.x

Terborgh, J. W., \& Andresen, E. (1998). The composition of Amazonian forests: patterns at local and regional scales. Journal of Tropical Ecology, 14, 645-664. https://doi.org/10.1017/S0266467498000455

Tuomisto, H., Poulson, A. D., Ruokolainen, K., Moran, R. C., Quintata, C., \& Celi, J. (2003). Linking floristic patterns with soil heterogeneity and satellite imagery in Ecuadorian Amazonia. Ecological Applications, 13, 352-371. https://doi.org/10.1890/1051-0761(2003)013[0352:LFPWSH]2.0.CO;2

Vormisto, J., Phillips, O. L., Ruokolainen, K., Tuomisto, H., \& Vasquez, R. (2000). A comparison of fine-scale distribution patterns of four plant groups in an Amazonian rainforest. Ecography, 23, 349-359. https://doi.org/10.1111/j.1600-0587.2000.tb00291.x

Walter, H. (1973). Vegetation of the earth and the ecological systems of the geo-biosphere. Springer-Verlag. Berlin. 


\section{Copyrights}

Copyright for this article is retained by the author(s), with first publication rights granted to the journal.

This is an open-access article distributed under the terms and conditions of the Creative Commons Attribution license (http://creativecommons.org/licenses/by/4.0/). 